\title{
20. LATE CENOZOIC OXYGEN AND CARBON ISOTOPIC CHANGES AT DSDP SITE 284: IMPLICATIONS FOR GLACIAL HISTORY OF THE NORTHERN HEMISPHERE AND ANTARCTICA
}

\author{
N. J. Shackleton, Sub-Department of Quaternary Research, University of Cambridge, England \\ and \\ J. P. Kennett, Graduate School of Oceanography, University of Rhode Island, Kingston, Rhode Island
}

\begin{abstract}
Stable isotope analyses of the benthonic foraminiferal genus Uvigerina from 39 samples at Site 284 , covering an interval from the late Miocene to early Pleistocene (approximately 6 to 1.5 m.y. B.P.), are interpreted in terms of glacially induced isotopic changes in the ocean. The Antarctic ice sheet was present throughout this interval. During the late Miocene its dimensions were less constant than they were during the Pliocene; during the New Zealand Kapitean Stage (latest Miocene; 4.7 to 4.3 m.y. B.P.) it was probably substantially greater than today, and a lesser advance may have occurred about 3.5 m.y. ago within the early Pliocene. Prior to the Kapitean Stage the ice sheet may have been smaller than today, and perhaps less stable. About 2.6 m.y. ago a substantial Northern Hemisphere ice sheet accumulated rather rapidly, and related isotopic and foraminiferal changes mark the base of the Waipipian Stage of New Zealand. A more extensive Northern Hemisphere glaciation occurred during the early Pleistocene (Hautawan Stage), and was of similar extent to the well-documented glaciations of the later Pleistocene. The oxygen isotopic changes coincide with changes in planktonic foraminiferal faunas considered by Kennett and Vella to represent significant late Cenozoic paleotemperature changes of surface waters. Carbon isotope analyses also document significant changes associated with these events, the cooling in the Kapitean Stage being particularly marked. We propose the term "Pre-glacial Pliocene" to distinguish that part of the Pliocene prior to about 2.6 m.y. B.P., when extensive Northern Hemisphere glaciations had not developed, from the late Pliocene after development of these ice sheets.
\end{abstract}

\section{INTRODUCTION}

Stable isotope analyses of Leg 29 samples are directed towards a critical evaluation of the glacial history of Antarctica during the Cenozoic. Two separate, and possibly time-independent events are presumed to have occurred during the Cenozoic. One is a direct isotope effect; the accumulation of the ice at present lodged on the Antarctic continent has changed the average isotopic composition of the oceans by about 1.0 per mil. The second is a temperature effect; the temperature structure of the present oceans depends upon the generation of bottom water at near-zero temperatures around Antarctica, and this process must have started during the Cenozoic.

The primary purpose of studying the sequence in detail at Site 284 is to evaluate the nature of paleoclimates prior to the initiation of Pleistocene-like climate some time in the late Pliocene. An important climatic event or events at about 2.5 to 3 m.y. ago has been widely reported (Hays and Opdyke, 1967; Stipp et al., 1967; Devereux et al., 1970; McDougall and Wen- sink, 1966; Kennett et al., 1971; Berggren, 1972), but the exact nature of this change and of the climate which preceded it has not been evaluated. It is necessary to evaluate this in order to understand the Pre-Pliocene record.

Site 284 (Figure 1) at $40^{\circ} 30.48^{\prime} \mathrm{S}, 167^{\circ} 40.81^{\prime} \mathrm{E}$ was drilled in a water depth of 1068 meters. The 22 cores obtained represent 166.8 meters of the 208 meters penetrated. The biostratigraphy of the site is described in a companion paper by Kennett and Vella (this volume), who also have provided the geochronology by reference to paleomagnetically dated sequences determined in New Zealand marine strata. Kennett and Vella (this volume) also examined in detail quantitative changes in the planktonic foraminiferal faunas and made paleoclimatic interpretations. Frequency oscillations in the cool-water foraminifer Neogloboquadrina pachyderma are considered to reliably reflect paleoclimatic change and are plotted for comparison against the oxygen and carbon isotope curves (Figures 2-4). Increases in frequencies of $N$. pachyderma represent cooler intervals. Ratio changes of the cool-water foraminifer $N$. pachy- 


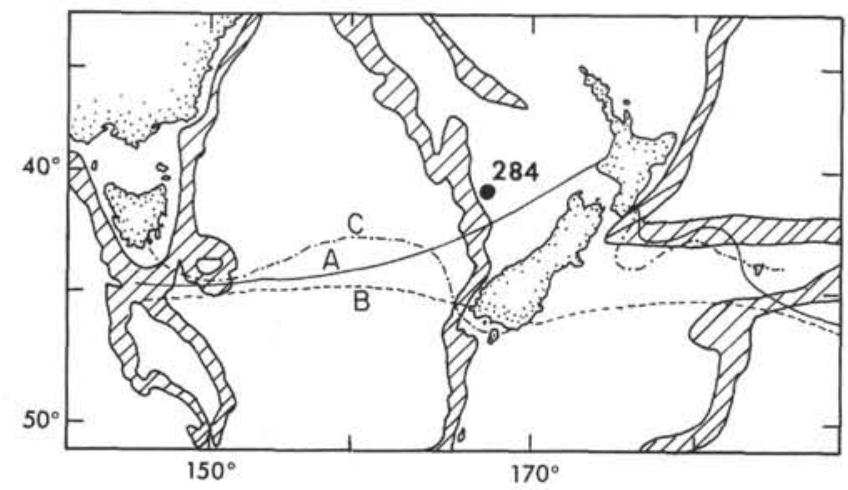

Figure 1. Location of DSDP Site 284 on the Challenger Plateau showing (A) the trend of the subtropical convergence according to Deacon (1937); (B) the southern limit of a zone of mixed waters which Fleming (1944) described between subantarctic and subtropical water; and (C) the general form of the subtropical convergence (after Garner, 1954).

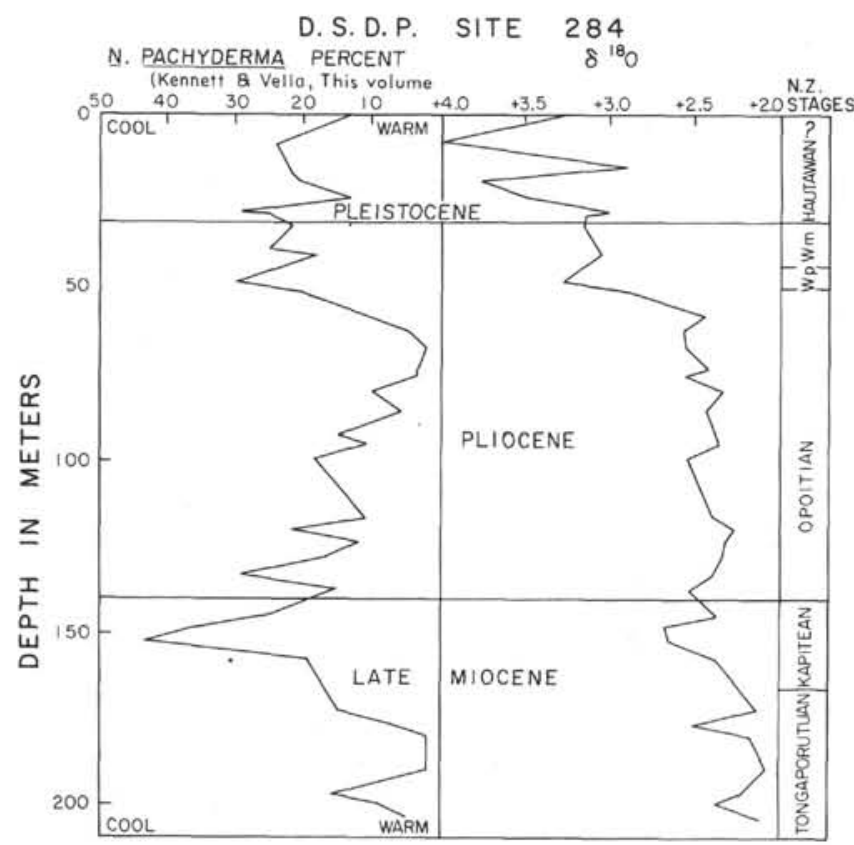

Figure 2. Oxygen isotopic composition of Uvigerina from Site 284 plotted against depth below ocean floor, with percentage $\mathrm{N}$. pachyderma (Kennett and Vella, this volume) and New Zealand stages. Data are from Table 1.

derma to the warmer-water form Globigerina falconensis are also considered by Kennett and Vella to clearly mark cool and warm intervals at Site 284 (Figure 4).

\section{ISOTOPIC EQUILIBRIUM AND PALEOTEMPERATURES}

Although the estimation of paleotemperatures from measurement of the isotopic composition of the oxygen in marine carbonate fossils is based on sound thermodynamic principles (Urey, 1947), the use of this tech-

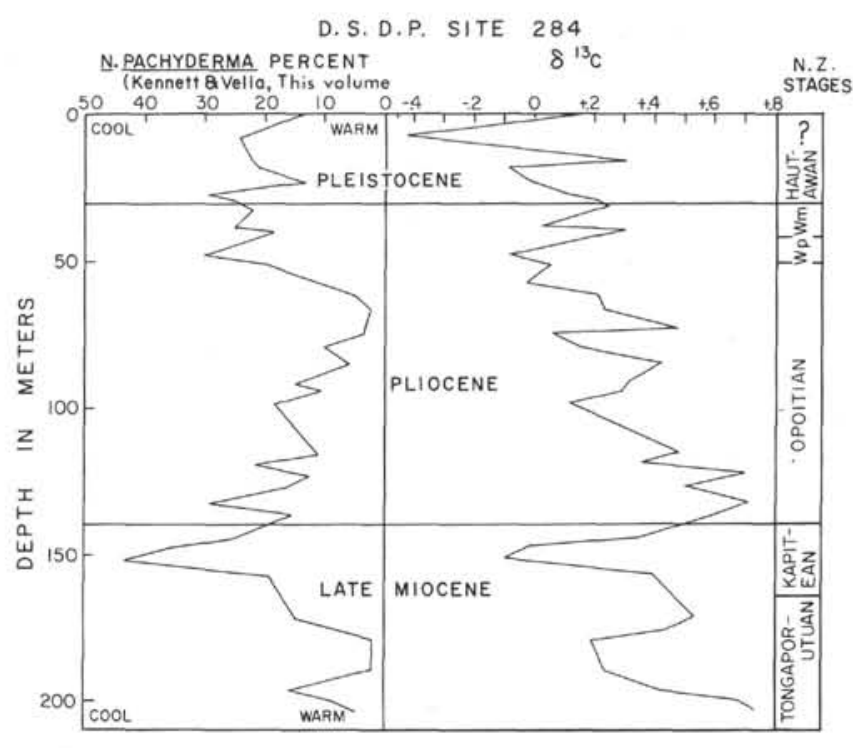

Figure 3. Carbon isotopic composition of Uvigerina from Site 284 plotted against depth below ocean floor, with percentage $\mathrm{N}$. pachyderma (Kennett and Vella, this volume) and New Zealand stages. Data are from Table 1.

nique in the Pleistocene has usually been somewhat empirical. Emiliani (1966) found that the variability among pretreatment and analytical methods was such that it was necessary to calibrate analyses empirically in terms of today's conditions. In terms of glacial samples, the correction to be made for varying ocean isotopic composition is so large and uncertain (Shackleton, 1967) that the method cannot at present be regarded as a physical means of measuring Pleistocene sea-surface temperatures.

Until recently, the situation was improved very little as far as abyssal temperatures were concerned. Duplessy et al. (1970) showed that different benthonic foraminiferal species deposit their tests out of isotopic equilibrium with seawater by varying amounts. This invalidates isotopic analyses of mixed benthonic species insofar as subtle interpretation is concerned. However, it is now known that abyssal uvigerinids do deposit their carbonate at, or very close to, isotopic equilibrium (Shackleton, in press).

Isotopic equilibrium may be expressed by the relationship:

$$
T=16.9-4.38\left(o_{c}-o_{w}\right)+0.10\left(o_{c}-o_{w}\right)^{2}
$$

This relationship is an expansion of that obtained by O'Neil et al. (1969) and is in the same form as obtained by Epstein et al. (1953) for molluscs. The mollusc data do not extend to sufficiently low temperatures for our purposes. Specimens of Uvigerina have now been analyzed in over 20 cores from the Pacific, Indian Ocean, and Subantarctic waters (Shackleton and Opdyke, 1973; Shackleton, in press and unpublished data). Specimens not more than about 6000 years old appear to average about $0.1 \pm 0.1$ per mil more negative than predicted by Equation 1, while glacial samples may be 


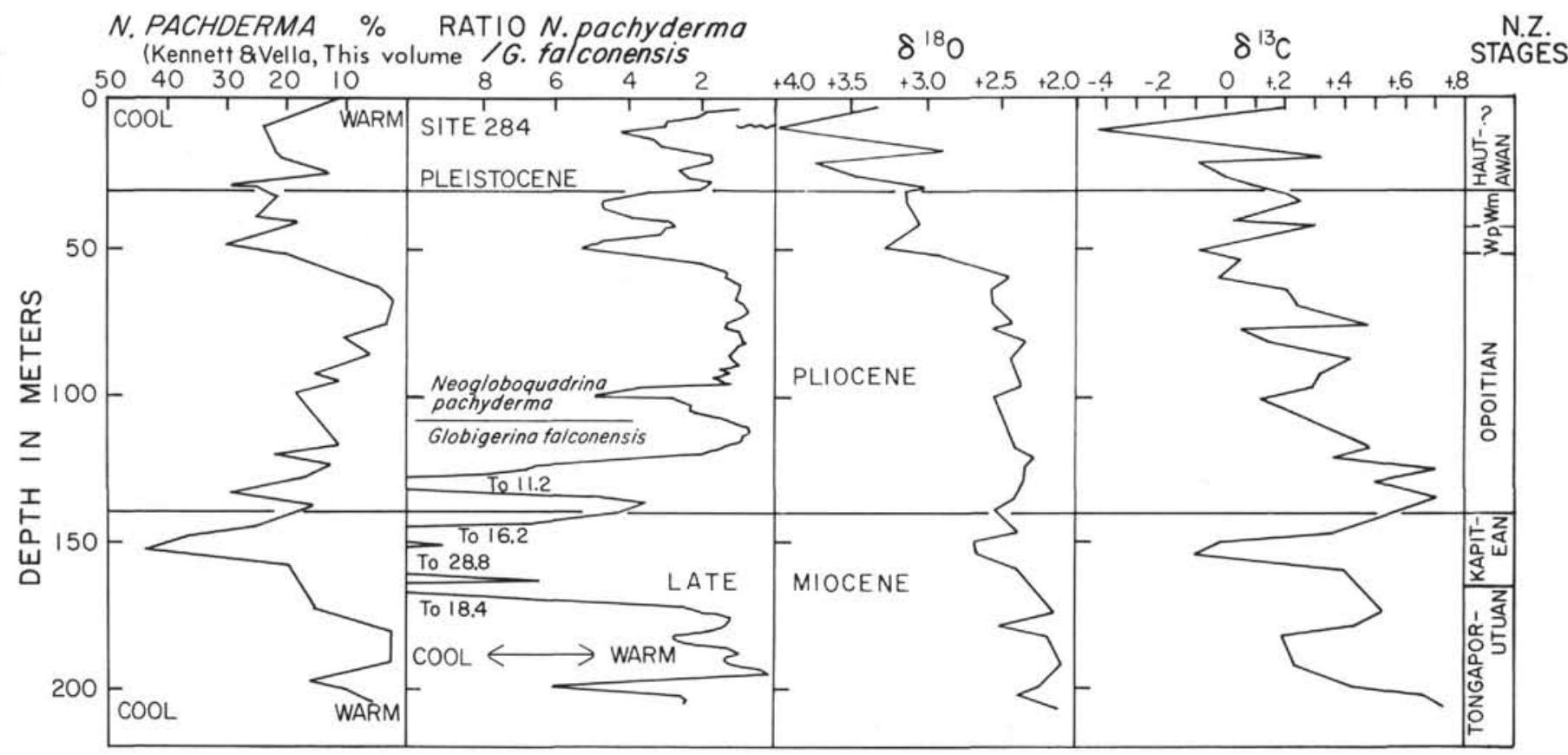

Figure 4. Oxygen and carbon isotopic composition of Uvigerina from Site 284 plotted against depth below ocean floor, with percentage of $\mathrm{N}$. pachyderma, and the ratio of $\mathrm{N}$. pachyderma to $\mathrm{G}$. falconensis (Kennett and Vella, this volume) and New Zealand stages.

up to 1.5 per mil more positive. This latter figure is a measure of the maximum deviation in ocean isotopic composition associated with Pleistocene glaciation in the Northern Hemisphere.

\section{EXPERIMENTAL METHOD}

Sample pretreatment, carbon dioxide release, and calibration procedures adopted were identical to those described by Shackleton and Opdyke (1973). Isotope analysis was performed in a new mass spectrometer, $\mathrm{V}$. G. Micromass $602 \mathrm{C}$; this has resulted in an improved analytical precision of \pm 0.05 per mil (1-o) which is valid for samples at least as small as $0.1 \mathrm{mg}$, the smallest analyzed here. Each sample contained between 4 and 15 individuals, the average individual weight being approximately $0.035 \mathrm{mg}$.

Analytical results, referred to the PDB standard, are given in Table 1. Oxygen isotope values are calibrated via the Emiliani B-1 standard, assuming its oxygen isotopic composition versus $\mathrm{PDB}$ to be +0.29 per mil (Friedman, personal communication; Shackleton, in press). Carbon isotope values are calibrated via the NBS-20 standard, assuming its carbon isotopic composition versus PDB to be -1.06 per mil (Craig, 1957). All analyses are presented in Table 1 and on Figures 2 and 3 .

\section{BASIS FOR INTERPRETATION OF RESULTS}

In the discussion which follows, it is assumed that the temperature of bottom water in the neighborhood of Site 284 has remained essentially unchanged since the late Miocene. The very stability of the record during the Opoitian Stage (early Pliocene) constitutes excellent evidence that the temperature structure was controlled like that of today. The nature of the glacial episodes should be tested by the determination of the oxygen isotope record at a deeper-water site. However, concerning the glacial extremes of the later Pleistocene, we have not found any reason to reject this model as a basis for interpreting isotopic changes in benthonic foraminifera.

\section{DISCUSSION OF ISOTOPIC RECORD}

\section{Pleistocene}

A stratigraphic break is present at about 10 meters (Kennett and Vella, this volume), and it appears that above this break, we have sampled one large-scale late Pleistocene glacial episode (Figure 2). The top sample measured perhaps may be only as old as 10,000 years. This is a similar value to that recorded for the upper parts of many piston cores. In the early Pleistocene below the disconformity, one major interglacial episode and one major glacial episode are recorded. These episodes are correlated with the Hautawan Stage of New Zealand, which has been shown by Kennett et al. (1971) to be of early Pleistocene age. The documentation of a major glaciation in the earliest Pleistocene (about 1.5 m.y. ago) is of significance since the earliest full glaciation previously documented is only about 800,000 years old (Shackleton and Opdyke, 1973).

\section{Mangapanian Stage (Latest Pliocene)}

It appears from the analyses obtained that the Mangapanian Stage (Figure 2) may have been characterized by a relatively stable Northern Hemisphere ice 
TABLE 1

Oxygen and Carbon Isotopic Composition ${ }^{\mathrm{a}}$ of Uvigerina from Site 284 and Percentage of Neogloboquadrina pachyderma of the Planktonic Foraminiferal Faunas

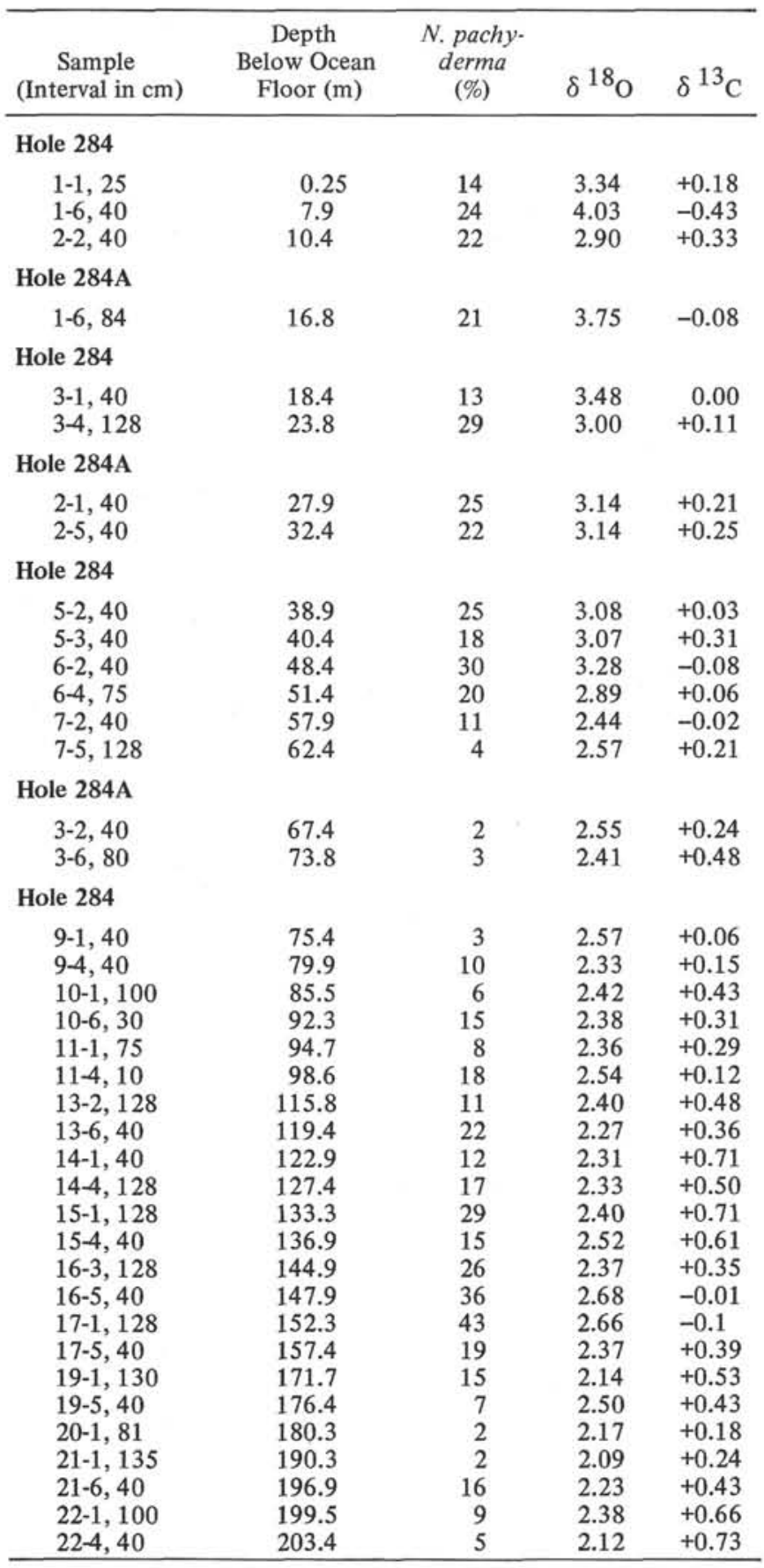

${ }^{\mathrm{a}}$ Expressed as deviations per mil from the PDB standard.

sheet of intermediate size. The ice sheet would be about half the size of the ice sheets which accumulated during the Brunhes Paleomagnetic Epoch ( $t=0$ to 0.69 m.y.). At present little information exists on climatic change within the early Matuyama Paleomagnetic Epoch. The inferred, rather stable paleoglacial record suggested for the latest Pliocene at Site 284 is of significance because it differs from the highly unstable, rapidly fluctuating paleoclimatic record of the late Pleistocene.

\section{Waipipian Stage (Late Pliocene)}

The isotopic composition of Uvigerina living at the site today may be estimated at $+2.60 \pm 0.1$ mil on the basis of a temperature of $4.85^{\circ} \mathrm{C}$ (Ridgeway, 1969, sta. G23/61), and a water isotopic composition (referred to PDB) of $-0.35 \pm 0.1$ per mil (Craig and Gordon, 1965, fig. 9). In the discontinuous Pleistocene section we have sampled two glaciations, one in the late Pleistocene, and one in the early Pleistocene Hautawan Stage. Prior to this, the latest Pliocene appears to have been associated with a moderate-sized Northern Hemisphere ice sheet, about one third to one half of its maximum mid-Pleistocene volume. The major and relatively rapid change in oxygen isotopes associated with the late Pliocene Waipipian Stage clearly records the first accumulation of this ice.

An isotopic change in the same stratigraphic position was observed by Devereux et al. (1970) in analyses in the Mangaopari Stream section, New Zealand. These workers noted that the isotopic values occurring before this transition were similar to those of the present day. They postulated the spread of glacial conditions into temperate latitudes no later than the Waipipian Stage and correlated this with an inferred eustatic fall in sea level (Vella, 1963). Kennett et al. (1971) dated this oceanic event at about 2.6 m.y. B.P., based on paleomagnetic stratigraphy.

The marked change in oxygen isotopes that is represented at Site 284 between 60 meters and 50 meters clearly represents the accumulation of Northern Hemisphere ice, supporting the conclusions of Devereux et al. (1970). Conditions prior to about 2.6 m.y. B.P. and after 4.1 m.y. B.P. appear to have been relatively stable and somewhat analogous to the rare true interglacials of the Pleistocene. It is interesting to note that climatic deteriorations, as evidenced by the increased percentage of $N$. pachyderma (Figure 2), and perhaps by the drop in $\delta^{13} \mathrm{C}$ (Figures 3 and 4), slightly precedes the major isotopic change. In the Labrador Sea, Berggren (1972) noted a minor influx of ice-rafted material near $3.0 \mathrm{~m} . \mathrm{y}$. ago, and a later major influx culminating some $2.6 \mathrm{~m} . \mathrm{y}$. ago. It seems certain that in this time interval we witness the climatic change necessary to enable Northern Hemisphere glaciation to commence, followed immediately by the onset of that glaciation.

Selli (1967) introduced the term "Pre-glacial Pleistocene" on the basis of his interpretation of Italian lower Pleistocene deposits. It is clear, however, that even though the European Alps may not have been glaciated at this time, North America must have been. Thus the use of this concept to explain differences in climatic conditions between the Matuyama and Brunhes Paleomagnetic epochs should be avoided. On the other hand, the study of the climates of the "Pre-glacial Pliocene" in comparison with the Recent, may enable us to better understand the instability of interglacial climate today. Thus we propose the term "Pre-glacial Pliocene" to distinguish that part of the Pliocene when Northern Hemisphere ice sheets were not present, from the late Pliocene interval (younger than about $2.6 \mathrm{~m} . y$. B.P.) when extensive Northern Hemisphere ice sheets had developed. The term does not infer any distinct relationship with glacial 
development of Antarctica, as this occurred before the Pliocene.

\section{Opoitian Stage (Early to Middle Pliocene)}

Perhaps the most remarkable feature of the oxygen isotopic record for the Opoitian Stage is its stability (Figure 2). The standard deviation among all the measurements is below \pm 0.1 per mil, interpretable in terms of a $\pm 10 \%$ variation in Antarctic ice volume, or at most, a $\pm 0.4^{\circ} \mathrm{C}$ temperature variation. Both of these values demonstrate conclusively, that not only was the Antarctic ice sheet present, but it was more or less limited to a constant size much like that of the present time (Hollin, 1962). This stability over some 2 m.y. strongly supports Hollin's arguments. In addition, the generation of bottom water must have been proceeding in essentially the same manner as today, in order to preserve this remarkable temperature stability.

In light of this observation, the most likely explanation for the gradual isotopic change through the Opoitian Stage (Figure 2) is a gradual subsidence of the sea floor at Site 284, sufficient to cause a drop in average bottom temperature of nearly a degree at this location. The significance of relatively minor changes that do occur during the Opoitian can only be evaluated after more detailed studies have been carried out. For example, a minor glacial advance is possibly recorded at about 3.5 m.y. (Core 9).

\section{Kapitean Stage (Latest Miocene)}

The distinct change in oxygen isotopic composition associated with the Kapitean Stage (Figure 2) (Core 16, Section 5 and Core 17, Section 1), can be interpreted in terms of a change in the quantity of ice on Antarctica. Two possibilities exist as to the extent of Antarctic ice buildup at this time. The first interpretation is that the maximum extent represented is about equivalent to the size of the present Antarctic ice sheet. In this case the minima represented before and after that of the Kapitean Stage represents an ice sheet roughly half the present-day size. This interpretation would permit bottom temperatures at the site to have been uniform throughout this interval. The second alternative is to interpret the long-term change at Site 284 as a gradual temperature drop associated with an ice sheet of present-day size. In this case the expansion observed during the Kapitean, would represent an ice volume about $50 \%$ more than that of the present day.

Deep Sea Drilling in the Ross Sea (Leg 28) revealed evidence of a substantial increase in the extent of the Antarctic ice sheet in late Miocene-early Pliocene (Hayes, Frakes, et al., 1973). Field work in Antarctica (e.g., Mayevsky, 1972) has also been interpreted in terms of an expanded ice sheet (see also Denton et al., 1971). Our data support the expansion of the Antarctic ice sheet during the latest Miocene.

If this explanation is correct, a gradual temperature decrease of almost $2^{\circ} \mathrm{C}$ in bottom-water temperatures has occurred at this site over the past few million years. However, this was probably due to local changes in bathymetry, rather than to any large-scale changes in ocean deep-water temperatures.

We conclude that during the latest Miocene (Kapitean Stage) the volume of ice stored in Antarctica increased to a volume $50 \%$ greater than is present today. Substantial cooling of surface waters that certainly must have resulted from such ice development on Antarctica, is shown by dramatic increases in the cool planktonic foraminifer $N$. pachyderma in the Kapitean Stage (Figures 2 and 3 ) and in the ratio of $N$. pachyderma to the warmer-water foraminifer G. falconensis (Figure 4). The oxygen isotopic record of this event should be easily recognized in deep-sea sediments from most of the oceanic area, providing a valuable stratigraphic marker. Further analyses at closer stratigraphic intervals are required to characterize the event in detail.

The associated glacio-eustatic sea-level lowering may be roughly estimated at 40 meters on the basis of an ocean isotopic change of about 0.5 per mil, and an isotopic composition for the removed water of -50 per mil. This assumes that the ice was all stored above sea level. Kennett (1967) summarized paleoenvironmental data from New Zealand marine late Miocene-early Pliocene sequences and suggested that a major regression occurred during the latest Miocene Kapitean Stage of New Zealand, followed by a transgression in the overlying early Pliocene Opoitian Stage. Because of the extent of this regression across various tectonic basins within New Zealand, possible simultaneous regression in other areas of the world, and association with an incursion of cool-water planktonic foraminiferal faunas, Kennett suggested that the regression was due to glacialeustatic changes. Our oxygen isotope data now show that this deduction was correct. Furthermore, paleodepth interpretations in these New Zealand marine sequences by Kennett $(1965,1966 \mathrm{a}, 1966 \mathrm{~b}, 1967)$ indicated that depths of deposition were in general greater, prior to the latest Miocene (Kapitean Stage) regression, than following it during the early Pliocene Opoitian Stage. If such depth differences resulted from glacial-eustatic causes, then it follows that much of the large volume of ice that built up during the Kapitean Stage remained on Antarctica even during a return to warmer early Pliocene climatic conditions. The late Miocene and early Pliocene oxygen isotope record at Site 284 (Figure 2) supports the glacial-eustatic explanation of changes in depth facies in New Zealand marine sequences originally proposed by Kennett (1967).

\section{Late Tongaporutuan Stage (Late Miocene)}

The oxygen isotope values show slight Antarctic glacial instability during the late Tongaporutuan Stage. The two isotopic excursions seen (Figure 2) represent ice volume changes roughly equivalent to one-third of the present ice sheet. It is not possible to say at present whether the ice sheet was smaller than the present day during some of this interval, but this is the simplest interpretation of the measurements. A more detailed study of this interval is critical for the understanding of the Antarctic ice sheet, when it was less firmly established than during the Pliocene-Pleistocene. 


\section{STRATIGRAPHIC VALUE OF THE MEASUREMENTS}

Changes in the bulk isotopic composition of ocean water have been demonstrated to be extremely useful in stratigraphic studies in the Pleistocene (Shackleton and Opdyke, 1973). It is clear from the present study that late Pliocene and latest Miocene to earliest Pliocene intervals should also be correlatable on a worldwide basis, with a high degree of precision using closely spaced isotope analyses.

\section{CARBON ISOTOPE ANALYSES}

The interpretation of changes in the isotopic composition of the carbon in foraminiferal carbonate is complex, and at present it is important that sufficient data are collected to establish coherent patterns (Douglas and Savin, 1971, 1973). It is possible that, similar to oxygen isotopes, a species-dependent departure exists from carbon isotopic equilibrium. It is not yet known whether Uvigerina deposits carbon in isotopic equilibrium with the dissolved bicarbonate. There is some evidence (unpublished) that if there is a departure, it remains fairly constant. Thus, the record of carbon isotopic change at Site 284 (Figures 3 and 4) almost certainly reflects climatically controlled changes in the isotopic composition of dissolved bicarbonate at this site. The cooling during the Kapitean Stage is particularly marked.

\section{CONCLUSIONS}

The oxygen isotope record from benthonic foraminifera at Site 284 provides a definitive record of the glacial history of the interval from the late Miocene (about 6 m.y. B.P.) to the early Pleistocene (about 1.5 m.y. B.P.). Its most important features are:

1) A major Antarctic ice sheet has been continuously present during the last $6 \mathrm{~m} . \mathrm{y}$.

2) An important expansion of the Antarctic ice sheet occurred during the latest Miocene Kapitean Stage of New Zealand and is dated as between about 4.7 to 4.3 m.y. B.P.

3) The initiation of Northern Hemisphere glaciation occurred within the late Pliocene about 2.6 m.y. ago and is reflected by planktonic foraminiferal faunal changes associated with the Waipipian Stage of New Zealand.

4) The oxygen isotopic changes coincide with distinct changes in planktonic foraminiferal faunas considered by Kennett and Vella (this volume) to represent substantial late Cenozoic paleotemperature oscillations in surficial waters.

\section{ACKNOWLEDGMENTS}

Isotope analysis was supported under NERC Grant GR3/1762 to NJS. The $602 \mathrm{C}$ mass spectrometer designed to our specifications by VG Micromass of Winsford, England, was purchased under this grant. The mass spectrometer was operated with meticulous care by M. A. Hall. Support to J.P.K. was by U.S. National Science Foundation Grant GA35252 (Geological Oceanography), and GV-(28305) Office of Polar Programs. Thanks are extended to Robert Thunell for technical assistance.

\section{REFERENCES}

Berggren, W. A., 1972. Late Pliocene-Pleistocene glaciation. In Laughton, A. S., Berggren, W. A., et al., Initial Reports of the Deep-Sea Drilling Project, Volume 12: Washington (U.S. Government Printing Office), p. 953-963.

Craig, H., 1957. Isotopic standards for carbon and oxygen and correction factors for mass-spectrometric analysis of carbon dioxide: Geochim. Cosmochim. Acta, v. 12, p. 133140.

Craig, H. and Gordon, L. I., 1965. Deuterium and oxygen 18 variations in the ocean and the marine atmosphere: Consig. Naz. Ric., Pisa, Italy, v. 122.

Deacon, G. E. R., 1937. Hydrology of the Southern Ocean: Discovery Rept. 15, p. 1-124.

Denton, G. H., Armstrong, R.L., and Stuiver, M., 1971. The Late Cenozoic glacial history of Antarctica: In Late Cenozoic glacial ages, Turekian, K. K. (Ed.), New Haven (Yale Univ. Press).

Devereux, I., Hendy, C. H., and Vella, P., 1970. Pliocene and early Pleistocene sea temperature fluctuations, Mangaopari Stream, New Zealand: Earth Planet. Sci. Lett., v. 8, p. $163-168$.

Douglas, R. G. and Savin, S. M., 1971. Isotopic analyses of planktonic foraminifera from the Cenozoic of the Northwest Pacific, Leg 6. In Fischer, A. C., Heezen, B. C., et al., Initial Reports of the Deep Sea Drilling Project, Volume 6: Washington (U.S. Government Printing Office), p. 11231127.

Duplessy, J. C., Lalou, C., and Vinot, A. C., 1970. Differential isotopic fractionation in benthic foraminifera and paleotemperatures reassessed: Science, v. 168, p. 250-251.

Emiliani, C., 1966. Palaeotemperature analysis of Carribbean cores P6304-8 and P6304-9 and a generalized temperature curve for the last 425,000 years: J. Geol., v. 74, p. 109-126.

Epstein, S., Buchsbaum, R., Lowenstam, H. A., and Urey, H. C., 1953. Revised carbonate-water isotopic temperature scale: Geol. Soc. Am. Bull., v. 64, p. 1315-1326.

Fleming, C. A., 1944. Molluscan evidence of Pliocene climatic change in New Zealand: Trans. Roy. Soc. New Zealand, v. 74 , p. $207-220$.

Garner, D. M., 1954. Sea surface temperature in the southwest Pacific Ocean from 1949 to 1952: New Zealand J. Sci. Tech. B36, p. 285-303.

Hayes, D. E., Frakes, L. A., Barrett, P. J., Burns, D. A., Chen, P.- H., Ford, A. B., Kaneps, A. G., Kemp, E. M., McCollum, D. W., Piper, D. J. W., Wall, R. E., and Webb, P. N., 1973. Leg 28 Deep-Sea Drilling in the Southern Ocean: Geotimes, v. 18, p. 19-24.

Hays, J. D. and Opdyke, N. D., 1967. Antarctic Radiolaria, magnetic reversals, and climatic change: Science, v. 158, p. 1001-1011.

Hollin, J. T., 1962. On the glacial history of Antarctica: J. Glac., v. 4, p. 173-195.

Kennett, J. P., 1965. Faunal succession in two upper Miocenelower Pliocene sections Marlborough, New Zealand: Trans. Roy. Soc. New Zealand, v. 3, p. 197-213.

1966a. Biostratigraphy and paleoecology in upper Miocene-lower Pliocene sections in Wairarapa and Southern Hawkes Bay: Trans. Roy. Soc. New Zealand, v. 4, p. 83-102.

1966b. Four upper Miocene to lower Pliocene sections, Hawke's Bay to East Cape, N. Z.: Trans. Roy. Soc. New Zealand, v. 4, p. 189-209.

1967. Recognition and correlation of the Kapitean Stage (upper Miocene, New Zealand): New Zealand J. Geol. Geophys., v. 10, p. 1051-1063. 
Kennett, J. P., Watkins, N. D., and Vella, P., (1971). Paleomagnetic chronology of Pliocene-early Pleistocene climates and the Plio-Pleistocene boundary in New Zealand: Science, v. 171, p. 276-279.

Mayevski, P. A., 1972. Glacial geology near McMurdo Sound and comparison with the Central Transantarctic Mountains: Antarctic J. U.S., v. 7, p. 103-106.

McDougall, I. and Wensink, H., 1966. Paleomagnetism and geochronology of the Pliocene-Pleistocene lavas in Iceland: Earth Planet. Sci. Lett., v. 1, p. 232-236.

O'Neil, J. R., Clayton, R. N., and Mayeda, T. K., 1969. Oxygen isotope fractionation in divalent metal carbonates: $\mathrm{J}$. Chem. Phys., v. 51, p. 5547-5558.

Ridgway, N. M., 1969. Temperature and salinity of sea water at the ocean floor in the New Zealand region: New Zealand J. Mar. Fresh-Water Res., v. 3, p. 57-72.

Savin, S. M. and Douglas, R. G., 1973. Stable isotope and magnesium geochemistry of Recent planktonic foraminifera from the South Pacific: Geol. Soc. Am. Bull., v. 84, p. $2327-2342$.
Selli, R., 1967. The Pliocene-Pleistocene boundary in Italian marine sections and its relationship to continental stratigraphies: Prog. Oceanogr., v. 4, p. 67-86.

Shackleton, N. J., 1967. Oxygen isotope analyses and Pleistocene temperatures reassessed: Nature, London, v. 215, p. 15-17.

, in press. Attainment of isotopic equilibrium between ocean water and the benthonic foraminifera genus Uvigerina: isotopic changes in the ocean during the last glacial: Paris (CNRS Colloque 219).

Shackleton, N. J. and Opdyke, N. D., 1973. Oxygen isotope and palaeomagnetic stratigraphy of Equatorial Pacific core V28-238: Oxygen isotope temperatures on a $10^{5}$ year and $10^{\circ}$ year scale: Quat. Res., v. 3, p. 39-55.

Stipp, J. J., Chappell, J. M. A., and McDougall, I., 1967. $\mathrm{K} / \mathrm{Ar}$ age estimate of the Pliocene-Pleistocene boundary in New Zealand: Am. J. Sci., v. 265, p. 462-474.

Urey, H. C., 1947. The thermodynamical properties of isotopic substances: J. Chem. Soc., p. 562-581.

Vella, P., 1963. Plio-Pleistocene Cyclothems, Wairarapa, New Zealand: Trans. Roy. Soc. New Zealand, Geology, v. 2, p. 15-50. 